О.В. Повстин, канд. екон. наук, доцент
(Львівський державний університет безпеки життєдіяльності) ПРАКСЕОЛОГІЧНИЙ ПІДХІД У ФОРМУВАННІ УПРАВЛІНСЬКОЇ
КОМПЕТЕНТНОСТІ МАЙБУТНІХ ФАХІВЦІВ У ГАЛУЗІ БЕЗПЕКИ ЛЮДИНИ

Розглянуто зміст поняття «праксеологія», розкрито суть праксеологічного підходу у формуванні управлінської компетентності майбутніх фахівців у галузі безпеки людини та можливості його використання у процесі професійної підготовки. Проаналізовано застосування праксеологічного підходу щодо формування у суб'єктів освітнього процесу (викладачів вищого навчального закладу, практичних працівників, задіяних до професійної підготовки майбутніх фахівців в галузі безпеки, студентів, курсантів). Також розглянуто уміння обирати ефективні технології його реалізації і навички результативно планувати й виконувати фахову діяльність в органах та підрозділах служби цивільного захисту, в інших державних структурах, які забезпечують безпеку в межах своїх компетенцій та повноважень, у подальшій діяльності.

Ключові слова: праксеологія, праксеологічний підхід, професійна підготовка, управлінська діяльність, управлінська компетентність, безпека.

O.V. Povstyn

\title{
ADMINISTRATIVE COMPETENCE FORMATION OF FUTURE SPECIALISTS IN THE FIELD OF THE HUMAN SECURITY: PRAXEOLOGICAL APPROACH
}

The concept "praxeology" and its content is considered in the article, the essence of the praxeological approach in the formation of managerial competence of future specialists in the field of human security and the possibilities of its use in the process of vocational training are discussed. The possibilities of using the praxeological approach to the formation of subjects in the educational process (teachers of higher educational institutions, practical workers involved in the training of future specialists in the field of security, students, cadets) are analyzed. The ability to choose effective technologies for its implementation and skills to effectively plan and carry out professional activities in civil protection agencies and departments, as well as in other state structures that provide security within the limits of their competencies and powers, in the further activities are also considered.

Key words: praxeology, praxeological approach, professional training, management activity, management competence, safety.

Постановка проблеми. Соціально-економічні процеси, що відбуваються в українському суспільстві, прагнення нашої держави інтегруватися в міжнародне співтовариство, ризики, загрози та небезпеки природного, техногенного і соціального характеру, які продукує і провокує соціум, а також особливі небезпеки, викликані військово-терористичними подіями на сході країни, потребують подальшого вдосконалення діяльності органів і підрозділів нашої держави, які відповідають за безпеку людини, в тому числі: пожежну, цивільну, екологічну, інформаційну, соціальну тощо. Однією з основних вимог до підготовки фахівців у галузі безпеки, в контексті наукового та освітнього пошуку, є наявність зв'язків між теорією і практикою у формуванні їхньої управлінської компетентності, що має свої специфічні особливості, відмінні для різних напрямів цієї галузі та потребує впровадження різноманітних інноваційних підходів.

Аналіз останніх досліджень та публікацій. Основою дослідження праксеології є класичні роботи А. Еспінаса, Т. Котарбінського. Л. фон Мізеса, С.Слуцького, Я. Коменського. Праксеологія виникла як загальна філософія і теорія практичної дії на рубежі XX і XXI століть, і стала набувати різноманітного дисциплінарного забарвлення. У сучасних наукових джерелах можна зустріти такі поняття як політична, юридична, соціальна, педагогічна праксеології. Все частіше застосовуються інноваційні підходи, сформовані на засадах філософії дії, наприклад, праксеологічну парадигму професійної освіти розглядали І.Колеснікова, К. Курода, М.Сацков, О.Грицанов, праксеологічно-правову проблематику досліджували О. Павлишин, С. Гусарєва. 
Невирішені раніше частини загальної проблеми. Основним завданням праксеології $\epsilon$ характеристика реальних людських можливостей, визначення об'єктивних i суб'єктивних дій, сприяння становленню ідеалів і цінностей особистості, оптимізація життєдіяльності і життєзабезпечення як в індивідуальному, так і суспільному контексті. У науковому пізнанні праксеологічна проблематика передбачає вивчення цілеспрямованої праксеологічної діяльності людей, спрямованої на перетворення природи і суспільства, відтворення продуктивних сил і суспільних відносин [1]. Разом з цим аналіз праксеологічної спрямованості формування управлінської компетентності майбутніх фахівців у галузі безпеки людини i орієнтованої на вироблення в курсантів та студентів професійно-управлінських умінь і навичок як системи засобів регуляції дій з управління, ще не знайшли належного відображення у дослідженнях науковців.

Постановка завдання. Метою статті є з'ясування сутності праксеологічного підходу як методологічного принципу та особливостей його застосування до професійної підготовки майбутніх фахівців у галузі безпеки життєдіяльності до управлінської діяльності.

Виклад основних положень. Вперше поняття «праксеологія» в кінці XIX століття застосував французький філософ та історик А. Еспінас (Alfred Espinas) і запропонував ідею створення окремої навчальної дисципліни про фактори підвищення ефективності і корисності дій. Наступний етап у розвитку праксеології відзначений працею польського філософа T. Котарбінського, який у середині XX століття опублікував «Трактат про хорошу роботу», що став основою формування праксеологічного підходу як специфічного способу аналізу людської діяльності в аспекті їі цілевідповідності, раціональності, ефективності. Дослідник трактує праксеологію як загальну теорію ефективної («справної») організації діяльності, що охоплює три групи проблем: аналітичний опис, характеристику, класифікацію і систематизацію практичних дій; вивчення умов і законів, що визначають ефективність дій; вивчення генези розвитку різних видів діяльності та шляхів їх удосконалення. На думку Т. Котарбінського, праксеологія є сферою наукового пізнання, яка синтезує дані різних наук, що стосуються організації праці, й охоплює лише аспекти, які притаманні будь-якій діяльності й мають загальний характер. Праксеологія - це типова модель організаційної науки, спрямована на напрацювання практичних порад, з асиміляцією й систематизацією даних з різних наук під кутом зору завдань цієї сфери діяльності [2].

В 1916-1922 р.p. з'явилася фундаментальна праця А. Богданова «Тектологія», присвячена організації різноманітних структур. Чотирма роками пізніше (1926) Є. Слуцький опублікував працю про формально-праксеологічні принципи економії, в якій незалежно від А. Еспінаса використовував термін «праксеологія». Всі ці проекти праксеології були взаємно незалежними, що свідчить про необхідність наукових досліджень про ефективні прийоми діяльності.

Відповідно, для організації й реалізації ефективної професійної підготовки майбутніх фахівців у галузі безпеки людини доцільно використовувати праксеологічний підхід, який дає змогу виявити загальні закономірності й принципи раціональної фахової діяльності, умови підвищення ефективності професійних дій та формує у курсантів та студентів вміння «бути практично успішними».

Праксеологічний аспект передбачає володіння прийомами самопізнання, що дають змогу виявити здібності та можливості, сильні і слабкі сторони власної особистості (у цьому контексті значну допомогу надають психологічні тести, самоаналіз, вивчення практичного досвіду інших людей); вміння будувати і коректувати свої життєві плани і стратегії, базуючись на самопізнанні та опираючись на власні можливості й допомогу педагогів, наставників, досвідчених фахівців; вміння орієнтуватися у складних ситуаціях, в яких обмаль інформації і можливий ризик, приймати рішення і діяти з урахуванням розумного ризику, аналізі власні i чужі помилки; володіння основними стратегіями діяльності у професійній сфері [1].

Використання ідей та принципів праксеології в навчально-виховному процесі закладу вищої освіти сприятиме підвищенню ефективності процесу професійної підготовки, що відповідає вимогам нової освітньої парадигми й сучасним соціально-економічним умовам в су- 
спільстві. Доцільним це стане і щодо формування управлінської компетентністі фахівців у галузі безпеки людини, що розглядається як суттєва складова їхньої професійної компетентності та самореалізації у фаховій діяльності. Тому закономірно, що їхня професійна підготовка до управлінської діяльності у ЗВО ДСНС України має спрямовуватися на:

- вироблення у курсантів і студентів мотиваційно-ціннісного ставлення до управлінської діяльності, усвідомлення потреби вдосконалення власних управлінських якостей;

- озброєння курсантів і студентів професійно значущими управлінськими знаннями, розвиток їхніх пізнавальних здібностей і потреб, а також здатності до ефективного сприймання й осмислення професійно важливої управлінської інформації;

- забезпечення практичної підготовленості випускників ЗВО ДСНС України до виконання управлінської діяльності на основі цілеспрямованого комплексного застосування управлінських умінь і навичок, зокрема в екстремальних ситуаціях;

- формування управлінської компетентності майбутніх фахівців у галузі безпеки людини як цілісної інтегрованої характеристики особистості та здатності до іiі реалізації під час виконання професійно-управлінських функцій у навчальній і подальшій діяльності в підрозділах.

У професійній підготовці майбутніх фахівців у галузі безпеки людини до управлінської діяльності умовно виокремлюємо чотири логічно пов'язані етапи: пропедевтичний; теоретичної управлінської підготовки; практичної управлінської підготовки, який і сприяє розвитку праксеологічного компонента; інтегрування управлінської компетентності.

Перший етап триває від вступу до ЗВО ДСНС України і протягом першого року навчання. Він спрямований на формування аксіологічного компонента управлінської компетентності, який передбачає чітке уявлення першокурсників про управлінську діяльність та управлінську компетентність офіцера ДСНС України, позитивне ставлення та стійкий інтерес до управлінської діяльності, посилення мотивації щодо отримання професії в галузі безпеки людини, демонстрацію ролі управлінських знань у професійній діяльності офіцера ДСНС, сприяння усвідомленню необхідності їх здобуття, вироблення управлінських умінь і навичок роботи в команді тощо.

Другий етап - теоретичної управлінської підготовки - спрямований на формування когнітивного та діагностичного компонентів управлінської компетентності курсантів і студентів, які відображають гнучкість їхнього мислення, здатність до аналізу й синтезу, систематизації та узагальнення відповідної інформації, створення внутрішнього плану управлінських дій відповідно до конкретної ситуації, зокрема екстремальної, та передбачення наслідків прийняття управлінських рішень тощо.

Третій етап - практичної управлінської підготовки - полягає в розвитку праксеологічного компонента управлінської компетентності майбутніх фахівців у галузі безпеки людини i спрямований на вироблення в них професійно-правлінських умінь і навичок як системи засобів регуляції дій з управління.

Четвертий етап - інтегрування управлінської компетентності - спрямований на розвиток у курсантів і студентів іiі рефлексивного компонента як чинника, що інтегрує всі компоненти управлінської компетентності в цілісну характеристику особистості як суб'єкта управлінської діяльності в галузі безпеки людини і забезпечує функціональну придатність майбутніх керівників у всіх рольових позиціях і різноманітних аспектах управління в підрозділі ДСНС.

Дотримання цих етапів у процесі організації та реалізації професійної підготовки майбутніх фахівців у галузі безпеки людини до управлінської діяльності забезпечує наступність, послідовність формування і розвитку в них належного рівня управлінської компетентності в подальшій роботі. 
В сучасних умовах, управлінець розглядається як представник інтелектуальної еліти суспільства - менеджер, фахівець системи управління, діяльність якого поєднує обов'язки посадовця та висококласного спеціаліста. Управління в галузі безпеки людини має значні особливості, зумовлені змістом та умовами діяльності, а також специфікою конкретного напряму (цивільного та пожежного захисту, кібербезпеки, екологічної безпеки, психологічного захисту тощо). Оскільки робота керівника підрозділу в цій галузі багатофункціональна і залежить від низки різноманітних обставин, йому доводиться виконувати різні групи функцій: мотиваційні, організаційні, контролюючі та ін. Окрім того, у його роботі виділяють ситуаційні завдання за видами посадових обов'язків (наглядово-профілактична діяльність, реагування на надзвичайні ситуації, робота з персоналом, управління конфліктами, організація колективної роботи, прийняття рішень, моніторинг діяльності та внесення коректив тощо).

Подальша їх деталізація дає такий перелік основних функцій керівників: пошук і опрацювання інформації, планування, проектування, мотивування підлеглих, організація та забезпечення роботи, координування, контроль, аналіз, коригування, оцінювання, прогнозування. Зазначимо, що екстремальні умови діяльності та виконання обов'язків, до яких мають бути готові фахівці в галузі безпеки людини, стимулюють їх до вироблення відповідних стратегій поведінки.

Найбільш успішною для роботи керівників у надзвичайних ситуаціях $\epsilon$ активноперетворювальна, наступальна, рішуча та гнучка стратегія діяльності, оскільки лише за такої поведінки фахівець здатен взяти під контроль події та впливати на них [3], використовуючи весь арсенал професійних засобів і способів управлінського впливу. Найважливішими складовими управлінської компетентності керівників у галузі безпеки людини є здатність приймати професійно виважені й обгрунтовані (у тому числі з етичної та юридичної точки зору) управлінські рішення та забезпечувати виконання працівниками підпорядкованих підрозділів поставлених завдань, часто непростих і ризикованих. Для ефективної роботи всі фахівці органів і підрозділів ДСНС України мають уміти чітко планувати і розподіляти робочий час та раціонально використовувати його. Показниками їхньої професійної діяльності є швидкість прийняття управлінських рішень та якісне виконання поставлених завдань у стислі терміни, незважаючи на непередбачувані обставини й ускладнення, що виникають.

Досвід професійної діяльності випускників ЗВО ДСНС України свідчить про високі вимоги до їхньої управлінської компетентності. Передусім формування управлінської компетентності нерозривно пов'язане з розвитком у майбутніх фахівців інноваційного підходу до виконання службових функцій [4].

3 точки зору праксеологічного підходу у формуванні управлінської компетентності майбутніх фахівців у галузі безпеки людини більш актуальною стає проблема підготовки керівників із розвинутим аналітичним мисленням, здатних ефективно вирішувати весь комплекс завдань, що стоять перед ними, а також постійно нарощувати науково-теоретичний потенціал і практичний досвід, в умовах бурхливого розвитку сучасних засобів запобігання та протидії надзвичайним ситуаціям, змін ії форм і способів ведення. Актуальність теоретичних і практичних аспектів покращення управлінської компетентності майбутніх фахівців у галузі безпеки людини $з$ метою якісного вирішення службових завдань, зумовлена передусім гуманізацією, демократизацією стосунків і децентралізацією управління в органах і підрозділах ДСНС. Професіоналізм управлінця характеризується готовністю не лише до збільшення масштабів управління, а, передусім, до зростання динаміки управлінських процесів, підвищення моральної та правової відповідальності перед суспільством. При цьому на перший план виходить проблема моральної складової особистості. Як керівник, фахівець мусить бути зразком моральної поведінки, а також уміти виховувати особистісно-ділові та професійно важливі якості в підлеглих, вправно керувати їхніми моральними якостями і психологічним станом.

Підготовка особового складу органів і підрозділів ДСНС України до професійної діяльності в екстремальних обставинах, які виникають під час природних, екологічних, техногенних і технічних аварій і катастроф, здійснюється поетапно й охоплює різні види підготов- 
ки. Зокрема для курсантів і студентів передбачено такі їі види: базова професійноекстремальна (загальна та спеціальна), контекстно-екстремальна (спеціально-екстремальна й оперативно-екстремальна), а також постекстремальна [5]. Протягом усього навчання здійснюється підготовка майбутніх фахівців до колективної діяльності, тренування їхньої злагодженої роботи, а також навчання виконанню управлінських функцій відповідно до подальших типових посадових обов'язків.

Взаємозв'язок з іншими загальнонауковими методиками робить ефективним упровадження праксеологічного підходу в таких формах роботи з підготовки майбутніх фахівців у галузі безпеки людини в рамках навчальних дисциплін «Робота з персоналом», «Організація управління діяльністю органів та підрозділів цивільного захисту», «Основи менеджменту».

Висновок. Отже, праксеологічна спрямованість навчального процесу збагачує його новими методами й технологіями, які орієнтують студентів на якісне та продуктивне виконання майбутньої діяльності завдяки оволодінню прийомами іiї раціоналізації: оптимальної організації часу; раціональної роботи з навчальним матеріалом; використання ефективних прийомів запам'ятовування матеріалу тощо. Реалізація праксеологічного підходу в підготовці майбутніх фахівців у галузі безпеки дає змогу курсантам, студентам спроектувати власну модель ефективної професійної діяльності, виявити причини виникнення можливих проблем і перешкод у практичній роботі, розробити стратегію успішної практичної діяльності з урахуванням іiі раціональності, ефективності, технологічності шляхом удосконалення освітнього середовища й досягнення високих результатів. Також, стверджуємо, що праксеологічний підхід, шляхом можливої інтеграції з іншими загальнонауковими підходами, може бути реалізований у більшості сучасних інноваційних форм навчання.

\section{Список літератури:}

1. Поліщук В.А. Праксеологічний підхід як інноваційна основа вдосконалення професійної підготовки майбутніх соціальних працівників. Науковий вісник Уэггородського національного університету. Серія : Педагогіка. Соціальна робота. - 2014. - Вип. 32. - С. 148-150.

2. Котарбинський Т. Развитие праксиологии. Польское обозрение. - 1962. - №12. C. $15-27$ c. 18.

3. Козяр М. М. Екстремально-професійна підготовка до діяльності у надзвичайних ситуаціях : монографія / М. М. Козяр. - Львів : Сполом, 2004. - 376 с.

4. Волкова О. П. Реализация инновационной политики в процеессе профессиональной подготовки специалистов / Высшее образование в России. - 2009. - № 6. - С. 23-26.

5. Колесникова И. А. Педагогическая праксеология [учеб. пособие для студ. высш. пед. учеб. заведений] / И. А. Колесникова, E. В. Титова. - М. : Издательский центр «Академия», 2005. - 256 с.

\section{References:}

1. Polishchuk V.A. Prakseolohichnyi pidkhid yak innovatsiina osnova vdoskonalennia profesiinoi pidhotovky maibutnikh sotsialnykh pratsivnykiv. Naukovyi visnyk Uzhhorodskoho natsionalnoho universytetu. Seriia : Pedahohika. Sotsialna robota. - 2014. - Vyp. 32. - S. 148-150.

2. Kotarbynskyi T. Razvytye praksyolohyy. Polskoe obozrenye. - 1962. - №12. - S.15-27 s.18.

3. Koziar M. M. Ekstremalno-profesiina pidhotovka do diialnosti u nadzvychainykh sytuatsiiakh : monohrafiia / M. M. Koziar. - Lviv : Spolom, 2004. - 376 s.

4. Volkova O. P. Realyzatsyia ynnovatsyonnoi polytyky v protsesse professyonalnoi podhotovky spetsyalystov / Vysshee obrazovanye v Rossyy. - 2009. - № 6. - S. 23-26.

5. Kolesnykova Y. A. Pedahohycheskaia prakseolohyia [ucheb. posobye dlia stud. vyssh. ped. ucheb. zavedenyi] / Y. A. Kolesnykova, E. V. Tytova. - M. : Yzdatelskyi tsentr «Akademyia», 2005. $-256 \mathrm{~s}$.

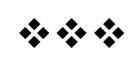

